\title{
PERBUATAN PIDANA YANG DILAKUKAN OLEH PENGEDAR NARKOTIKA DENGAN MENGGUNAKAN TEKNOLOGI INTERNET DAN APLIKASI VPN
}

\author{
Hendro Utaryo \\ Universitas Airlangga \\ hendrou42@gmail.com
}

\begin{abstract}
The growing population and the development of communication technology led to the increasing use of Internet technology. Narcotics circulation through the development of Internet technology and VPN applications is the impact of misuse of the positive functions of a technology that has evolved into negative functions and against the law. The use of technology that has evolved from a communication device by the narcotics distributor to market their narcotics trading quickly, briefly, and veiled with the intent of activities that will be disseminating and trading narcotics not May be known by the authorities. This research uses normative research method by analyzing about criminal action conducted by narcotics distributor using Internet based technology and VPN application as well as determining locus delicti from The cause of the cyberlaw and its accountability for narcotics dealers.
\end{abstract}

Keywords: Narcotics, Technology, Internet.

\begin{abstract}
Abstrak
Pertumbuhan penduduk yang semakin padat dan perkembangan teknologi komunikasi menyebabkan semakin meningkatnya penggunaan teknologi internet. Peredaran Narkotika melalui perkembangan teknologi Internet dan aplikasi VPN merupakan dampak penyalahgunaan fungsi positif dari suatu teknologi yang sudah berkembang menjadi fungsi negatif dan melawan hokum. Penggunaan teknologi yang sudah berkembang dari alat komunikasi oleh pengedar Narkotika untuk memasarkan dagangan Narkotika mereka dengan cepat, singkat, dan terselubung dengan maksud kegiatan yang dilakuakan baik penyebaran dan perdagangan Narkotika tidak dapat diketahui oleh pihak yang berwajib. Penelitian ini menggunakan metode penelitian normatif yakni dengan menganalisis tentang perbuatan pidana yang dilakukan oleh pengedar narkotika dengan menggunakan teknologi yang berbasis internet dan aplikasi VPN sekaligus penentuan locus delicti dari perkara yang terjadi dari sisi cyberlaw beserta pertanggungjawaban pidananya bagi pelaku pengedar Narkotika.
\end{abstract}

Kata Kunci: Narkotika, Teknologi, Internet. 


\section{PENDAHULUAN}

Pertumbuhan penduduk, perkembangan ilmu pengetahuan, perkembangan teknologi dan pembangunan akhir-akhir ini menjadi topik pembahasan yang menarik terutama apabila hal-hal tersebut disampaikan bersamaan dengan isu politik. Akan tetapi hal tersebut tidak bisa terlepas dengan aturan hukum yang ada dan terbentuk karena adanya politik hukum yang dianut oleh negara, terlebih negara kita Indonesia ini adalah rechtstaat (Negara hukum) sebagaimana terefleksikan kedalam konstitusi UUD 1945 NRI Pasal 1 ayat (3) yang berbunyi, "Negara Indonesia adalah negara hukum”. Oleh karena itu setiap perbuatan dan tindakan kita hendaknya dan seyogyanya mematuhi aturan hukum yang telah disepakati bersama. Sehingga demi terciptanya masyarakat yang adil dan makmur, maka negara dalam hal ini bereperan penting dengan melakukan pembangunan secara merata dalam segala bidang, sebagaimana yang sedang terjadi saat ini di negara kita. Adapun salah satu tujuan pembangunan yang dilakukan oleh setiap bangsa adalah menciptakan kualitas manusia yang mampu melanjutkan perjuangan dan misi bangsa. Lebih khusus lagi peningkatan kualitas Sumber Daya Manusia tersebut ditujukan pada generasi muda khususnya remaja baik Pelajar SD, SMP, SMA dan Mahasiswa. Sebagai penerus perjuangan cita-cita bangsa generasi muda adalah sebagai obyek pembangunan, ia sangat diharapkan menjadi salah satu aset pembangunan yang benar-benar berkualitas. Kualitas manusia Indonesia sebagai sumber daya pembangunan bangsa tersebut sangat banyak ditentukan oleh kesehatannya, baik jasmani maupun rohaninya. ${ }^{1}$

Sehingga dengan adanya permasalahan penyalahgunaan Narkotika yang merupakan permasalahan serius, hal ini dapat menggangu kualitas manusia Indonesia, dimana kualitas manusia Indonesia adalah sebagai sumber daya pembangunan bangsa ini. Permasalahan ini tidak hanya menjadi masalah nasional dan beberapa negara saja akan tetapi permasalahan penyalahgunaan Narkotika sudah menjadi permasalahan dunia. Di sisi lain dalam hidup bermasyarakat dan bernegara demi terciptanya kerukunan, keamanan, ketertiban dan kenyamanan dibutuhkannya komunikasi antara yang satu dengan yang lain, baik itu antara penduduk yang yang satu dengan yang lain atau antara penduduk dengan

\footnotetext{
${ }^{1}$ Masruhi,Sudiro, Islam melawan narkoba, Yogyakarta:Madani Pustaka,2000, h. 1

${ }^{2}$ http://repository.uksw.edu/bitstream/123456789/9106/2/T0_562011007_BAB\%20II.pdf,
} 
pemerintah. Dimana komunikasi yang terjadi tersebut juga tidak luput dari objek pembangunan dan didalam komunikasi tersebut harus menggunakan etika dan norma yang sudah diatur oleh negara, komunikasi yang terjadi sudah tidak lagi dibatasi oleh ruang dan waktu, serta menggunakan beranekaragam cara untuk berkomunikasi.

Di antaranya dengan menggunakan sarana-prasarana alat komunikasi yang dimiliki baik itu menggunakan telepon konvensional, teknologi internet, ataupun Telepon GSM (Global System for Mobile Communications) yang biasa dimaknai oleh manusia pada jaman sekarang yaitu handphone atau celullar phone. GSM ${ }^{2}$ (singkatan bahasa Inggris : Global System for Mobile Communications, GSM) adalah salah satu standar sistem komunikasi nirkabel(wireless) yang bersifat terbuka yang digunakan oleh Handphone. Handphone digunakan oleh lebih dari satu milyar orang di lebih dari 200 negara, banyaknya standar Global System for Mobile Communications(GSM) ini membuat roaming Internasional sangat umum dengan "persetujuan roaming" antar operator telepon genggam. Ada pun pengertian lain dari Global System for Mobilecommunication (GSM) adalah sebuah standar global untuk komunikasi bergerak digital.

Global System for Mobile Communications(GSM) adalah nama dari sebuah group standarisasi yang dibentuk di Eropa tahun 1982 untuk menciptakan sebuah standar bersama telepon bergerak selular di Eropa yang beroperasi pada daerah frekuensi 900MHz. Handphone itu sendiri pada jaman sekarang sudah menjadi alat komunikasi yang fenomenal karena selain bisa digunakan sebagai alat komunikasi dengan mngirimkan suara juga bisa digunakan mengirim pesan text yang lazim disebut sebagai SMS (dari bahasa Inggris: Short Message Service) dan sebagai sarana untuk mencari informasi serta bertukar informasi.

Di samping itu teknologi komunikasi itu sendiri semisal Handphone mempunyai beberapa sistem operasi yang beraneka ragam, mulai dari Java, Symbian, Windows dan terkini adalah Android. Handphone yang menggunakan sistem operasi terbaru yaitu Android serta berbasis internet didalamnya juga tidak lupa berisi aplikasi media sosial yang mana juga banyak digunakan oleh

\footnotetext{
${ }^{2}$ http://repository.uksw.edu/bitstream/123456789/9106/2/T0_562011007_BAB\%20II.pdf, diunduh pada hari Sabtu tanggal 13 April 2019 pukul 01.00 wib.
} 
masyarakat dunia untuk berkomunikasi ataupun hanya bertukar data informasi dan di Indonesia sendiri bisa kita lihat penggunaan mesin pencari (Search Engine) seperti Google atau Mozilla firefox dan yang lainnya, namun yang paling populer dikalangan para pengguna media sosial diantaranya adalah Facebook, Twitter, BBM, WhatsApp, Instagram, Telegram dan banyak yang lainnya. Dimana kemajuan dan inovasi teknologi dibidang komunikasi tersebut tidaklah luput dari penyalahgunaan oleh pihak-pihak yang tidak bertanggungjawab.

Dengan adanya penyalahgunaan teknologi yang notabene adalah bagian dari hasil pembangunan dibidang komunikasi yang dilakukan oleh pihak yang tidak bertanggungjawab, semisal penyalahgunaan yang dilakukan oleh para pengedar Narkotika, maka hal ini dapat menyebabkan pembangunan yang dilakukan oleh pemerintah khususnya dalam hal sumber daya manusia menjadi terhambat. Adapun salah satunya dari tindakan pengedar Narkotika didalam melakukan upaya pengedarannya yaitu didahului dengan upaya komunikasi terlebih dahulu untuk menentukan besaran Narkotika yang akan diperdagangkan dan lokasi titik pertemuan untuk pengantaran dan pengambilan atau penjemputan Narkotika yamg dimaksud, hal ini dilakukan sekiranya agar tidak diketahui oleh pihak yang yang berwajib atau dalam ini pemerintah, dan komunikasi tersebut menggunakan teknologi yang serba canggih dan modern saat ini yaitu didalam komunikasi tersebut menggunakan teknolgi internet yang sebelumnya didahului dengan tindakan penyamaran IP Address untuk akses internet mereka terlebih dahulu, hal ini dimaksudkan agar dari tindakan komunikasi tersebut tidak dapat diketahui dari mana asal titik komunikasi atau dengan kata lain alamat pasti dari keberadaan pengedar Narkotika dalam melakukan komunikasi sebagai bentuk bagian dari transaksi sebelum dilakukannya pengiriman Narkotika, sehingga pada saat pemerintah atau aparat yang berwajib melalui perangkatnya yaitu Kepolisian dan Badan Narkotika Nasional (BNN) berkeinginan untuk memberantas peredaran Narkotika yang dapat menyebabkan pembangunan bangsa dan negara ini terhambat atau mengalami kesulitan untuk mengungkap kejahatan yang sedang dilakukan, oleh karenanya dengan adanya tindakan yang dilakukan oleh para pengedar Narkotika dalam menggunakan teknologi internet untuk melakukan transaksinya maka hal ini menyebabkan pemerintah melalui perangkatnya yaitu 
Kepolisian dan Badan Narkotika Nasional (BNN) sangat kesulitan dalam memberantas peredaran Narkotika tersebut dan mencoba untuk menangkap para pengedar Narkotika khususnya pengedar Narkotika yang mempunyai jalur peredaran Internasional yang ada di negara Indonesia.

Perlu juga diketahui secara bersama bahwa IP Address (internet protocol address) itu sendiri adalah merupakan deretan angka biner antara 32 bit sampai dengan 128 bit yang digunakan sebagai alamat identifikasi untuk tiap komputer host dalam jaringan internet. Angka 32 bit digunakan untuk alamat IP Address versi IPv4 dan angka 128 bit digunakan untuk IP Address versi IPv6 untuk menunjukkan alamat dari komputer pada jaringan internet berbasis TCP/IP. IP Address tersebut memiliki identitas numerik yang akan dilabelkan kepada suatu device seperti komputer, router atau printer yang terdapat dalam suatu jaringan komputer yang menggunakan internet protocol sebagai sarana komunikasi. ${ }^{3}$ Adapun penyamaran IP Address yang digunakan untuk mengakses internet saat ini adalah bukan suatu hal baru, dimana hal ini dengan kemajuan teknologi yang ada dapat dilakukan oleh siapun secara mudah dengan menggunakan aplikasi Virtual Private Network (VPN) baik yang bisa didapatkan secara gratis atau berbayar, dimana fungsi dari Virtual Private Network (VPN) yang digunakan pengedar Narkotika tersebut adalah untuk mengelabui pemerintah dalam hal ini aparat Kepolisian dan Badan Narkotika Nasional (BNN), dengan cara membuat alamat IP Address semu atau palsu dalam penggunaan akses internet mereka sehingga seakan-akan keberadaan mereka para pengedar pada saat bertransaksi dan berkomunikasi bisa berpindah-pindah dari satu alamat ke alamat lainnya atau bahkan dari satu negara ke negara lainnya.

Fenomena peredaran Narkotika yang terjadi dengan menggunakan teknologi canggih hasil dari pembangunan yang salah satunya adalah menggunakan alat komunikasi yang berbasis internet adalah sebagai akibat dari berkembangnya teknologi komunikasi dan informasi yang telah menimbulkan permasalahan hukum baru di Indonesia, dimana hal ini seharusnya menjadi hal yang positif bagi bangsa dan negara akan tetapi justru sebaliknya berbalik arah dan menyulitkan pemerintah dalam melakukan pemberantasan peredaran Narkotika.

\footnotetext{
${ }^{3}$ http://technopark.surakarta.go.id/id/media-publik/komputer-teknologi-informasi/191-ipaddress-fungsi-dan-kelas-ip diakses pada hari Sabtu tanggal 13 April 2019 pukul 01.30 wib.
} 
Berbicara Virtual Private Network atau biasa disebut VPN adalah sebuah cara aman untuk mengakses internet di dalam local area network yang berada pada jangkauan tertentu, dengan menggunakan internet atau jaringan umum lainnya untuk melakukan transmisi data paket secara pribadi. Dimana salah satu fungsi sebenarnya adanya VPN adalah keamanan dalam berkomunikasi atau dalam pertukaran data, juga tidak memungkinkan pihak lain untuk menyusup ke traffic (lalu lintas jaringan) yang tidak semestinya. ${ }^{4}$

Berdasarkan uraian di atas penulis tertarik untuk meneliti dan menganalisis tentang perbuatan pidana yang dilakukan oleh pengedar narkotika dengan menggunakan teknologi yang berbasis internet dan aplikasi VPN, mengingat banyaknya kasus yang terjadi saat ini terkait hal tersebut. Penulis juga tertarik penentuan locus delicti dari perkara yang terjadi dari sisi cyberlaw beserta pertanggungjawaban pidananya bagi pelaku pengedar Narkotika.

\section{METODOLOGI}

Metode penelitan hukum pada jurnal ini menggunakan metode penelitian yuridis normatif dengan pendekatan perundang-undangan (statute approach) terkait narkotika dan peraturan yang relevan serta pendekatan konseptual (conseptual approach) yang mengkaji teori-teori dan doktrin-doktrin dari para ahli dibidang Pidana Cybercrime.

\section{PEMBAHASAN}

\section{Pertanggungjawaban Pidana Pelaku Pengedar Narkotika}

Pertanggungjawaban pidana dalam bahasa asing disebut sebagai "toerekenbaarheid", "criminal responsibility", "criminal liability", pertanggungjawaban pidana ini dimaksudkan untuk menentukan apakah seseorang tersebut dapat dipertanggungjawabkan atas pidananya atau tidak terhadap tindakan yang dilakukan itu. ${ }^{5}$ Hukum pidana adalah hukum publik yang mana disini hukum pidana merupakan seorang panglima yang membela kepentingan yang utama yaitu kepentingan umum dengan menomor duakan kepentingan pribadi seperti ganti kerugian. Jadi jika terjadi suatu perbuatan pidana yang dilakukan oleh seseorang maka negara melalui alat-alatnya bertindak menghukum seseorang yang telah

${ }^{4}$ https://www.it-jurnal.com/pengertian-vpn-virtual-private-network/ diakses pada hari Sabtu tanggal 13 April 2019 pukul 01.45 wib.

5 S.R Sianturi, Asas-Asas Hukum Pidana Indonesia dan Penerapannya, Cet. IV, Alumni Ahaem-Pateheam, Jakarta, 1996, h. 245 
melakukan tindakan pidana tersebut dengan menjatuhkan sanksi, bisa berupa sanksi pidana ataupun tindakan.

Pertanggungjawaban pidana menjurus kepada pemidanaan pelaku, jika telah melakukan suatu tindak pidana dan memenuhi unsur-unsurnya yang telah ditentukan dalam Undang-undang. Sedangkan dalam pasal-pasal KUHP itu sendiri, unsur-unsur delik dan unsur pertanggungjawaban pidana bercampur aduk dalam buku II dan III, sehingga dalam membedakannya dibutuhkan seorang ahli yang menentukan unsur keduanya. Menurut pembuat KUHP syarat pemidanaan disamakan dengan delik, oleh karena itu dalam pemuatan unsur-unsur delik dalam penuntutan haruslah dapat dibuktikan juga dalam persidangan.

Adapun asas yang mendasari pertanggungjawaban pidana adalah asas geen straff zonder schuld yang artinya tiada pidana tanpa kesalahan. Berkaitan dengan pertanggungjawaban pidana, ada beberapa hal yang penting dicatat dibawah ini, yaitu :6

a. Unsur kesalahan:

1) Melakukan tindak pidana.

2) Diatas umur tertentu dan mampu bertanggung jawab.

3) Dengan kesengajaan atau kealpaan.

4) Tidak ada alasan pemaaf.

b. Bentuk atau corak kesalahan:

1) Dengan kesengajaan.

2) Dengan kealpaan.

Berdasarkan dari pemahaman diatas bagi pelaku tindak pidana agar dapat dikenai sanksi pidana terhadap perbuatan pidana yang telah dilakukan maka sudah menjadi kewajiban dan keharusan bahwa unsur-unsur pertanggungjawaban pidana tersebut diatas harus terpenuhi. Dengan kata lain hukum pidana dengan keunikannya tetap menerapkan prinsip kehati-hati di dalam memberikan sanksi pidananya terhadap pelaku perbuatan pidana dengan memperhatikan unsur pertanggungjawaban pidananya apakah sudah terpenuhi.

Moeljatno dalam bukunya Asas-asas Hukum Pidana menyatakan “pertanggungjawaban pidana tidak cukup dengan dilakukannya perbuatan pidana saja, akan tetapi di samping itu harus ada kesalahan, atau sikap batin yang dapat dicela, ternyata pula dalam asas hukum yang tidak tertulis tidak dipidana jika

\footnotetext{
${ }^{6}$ Didik Endro Purwoleksono, Hukum Pidana, Airlangga University Press, 2014, h. 63
} 
tidak ada kesalahan (green straf zonder schuld, ohne schuld keine strafe)". Unsurunsur pertanggungjawaban pidana sebagai berikut : ${ }^{7}$

a. Adanya perbuatan yang dilakukan.

Dimaksud dengan perbuatan di sini adalah merupakan tindakan, aktivitas, atau kegiatan seseorang dalam hal ini pelaku, yang mana pada prinsipnya perbuatan tersebut apakah perbuatan tindak pidana atau bukan perbuatan tindak pidana. Berdasarkan Kamus Besar Bahasa Indonesia (KBBI) adalah sesuatu yang diperbuat (dilakukan) atau tindakan. Jika perbuatan tersebut merupakan perbuatan tindak pidana maka perbuatan yang dilakukan tersebut diatur di dalam Undangundang atau ada aturan hukumnya dan berbentuk sebuah kejahatan yang berbuah sanksi pidana. Jika tidak diatur di dalam Undang-undang mengenai sanksi pidananya maka hal tersebut merupakan sebuah perbuatan pelanggaran.

a. Perbuatan yang dilakukan apakah dikarenakan kesengajaan (dolus) atau kelalaian (culpa/schuld) .

Kesengajaan (dolus=opset) sendiri di dalam KUHP tidak diatur tegas mengenai kalimat sengaja, akan tetapi jika kita mencoba memahami Pasal-pasal di dalam KUHP atau dalam hal ini Undang-undang Informasi dan Transaksi Elektronik kita dapat mengetahui bahwa suatu perbuatan adalah sebuah kesengajaan dengan adanya frasa-frasa yang tertulis dalam suatu norma, misalnya sebagai berikut : 8

1) Dengan maksud.

2) Dengan mengetahui.

3) Berkehendak.

4) Dengan rencana.

5) Dengan tujuan.

6) Dengan paksa (lihat Pasal 167 KUHP).

7) Dengan kekerasan (lihat Pasal 212 KUHP).

8) Menghasut.

9) Memalsu surat atau membuat surat palsu.

Dalam kesengajaan terdapat dua teori, yaitu teori kehendak dan teori pengetahuan." "Teori kehendak adalah sesorang dikatakan melakukan kesengajaan, memang dia berkehendak melakukan tindak pidana tersebut. Dia pun

\footnotetext{
${ }^{7}$ Roeslan Saleh, Pikiran-pikiran Tentang Pertanggungjawaban Pidana, Ghalia Indonesia, Jakarta, 1982, h. 75-76

${ }^{8}$ Didik Endro Purwoleksono, op.cit, 2014, h. 69

${ }^{9}$ Ibid
} 
siap menanggung segala akibat dari tindak pidana yang dilakukannya. Misalnya A berkehendak membunuh B. Sarjana yang mendukung teori ini adalah Von Hipel dan Simmons. Teori pengetahuan adalah seseorang dikatakan melakukan perbuatan tindak pidana dengan kesengajaan, manakala dia mengetahui apa yang dia lakukan dan dia mengetahui apa akibat dari tindak pidana yang dilakukannya. Sarjana yang mendukung teori ini adalah Frank". ${ }^{10}$

Kealpaan (culpa/schuld) atau sembrono atau teledor menurut KBBI adalah suatu kelalaian atau kelengahan. Dalam hukum pidana kealpaan (culpa/schuld) itu sendiri juga diatur akan sanksi pidananya. Karena hukum pidana kita tidak mentolerir terhadap keteledoran seseorang yang dapat merugikan orang lain atau bahkan bisa membahayakan nyawa orang lain.

Beberapa pandangan beberapa sarjana tentang kealpaan : ${ }^{11}$

1) Hazewinkel Suringa

(a) Kurang penduga-duga.

(b) Kurang penghati-hati.

2) Van hamel

Kealpaan mengandung 2 syarat:

(a) Tidak mengadakan penduga-duga sebagaimana diharuskan oleh hukum.

(b) Tidak mengadakan penghati-hati sebagaimana diharuskan oleh hukum.

3) Simons

Pada umumnya kealpaan mempunyai unsur :

(a) Tidak adanya penghati-hati.

(b) Dapat diduganya akibat.

Dari kesengajaan (dolus) atau kelalaian (culpa/schuld) kita juga harus memahami bahwa tindak pidana kejahatan perlu kesengajaan atau kelalaian yang dapat menyebabkan timbulnya sanksi pidana, sedangkan tindak pidana pelanggaran tidak perlu adanya kesengajaan atau kelalaian sehingga yang timbul dapat berupa ganti rugi.

b. Melakukan kesalahan.

Unsur kesalahan disini erat kaitanya dengan kesengajaan atau kelalaian di dalam tindak pidana yang mana merupakan bentuk dari suatu kejahatan dengan sanksi pidananya bukan kesalahan dari bentuk pelanggaran. Kesalahan merupakan unsur mutlak di dalam hukum pidana kita, kesalahan dalam asas hukum pidana

\footnotetext{
${ }^{10}$ Ibid

${ }^{11}$ Ibid, h. 74
} 
Indonesia actus non facit reum nisi mens sit rea yang artinya adalah tiada pidana tanpa kesalahan (geen straf zonder schuld).

Pemahaman tiada pidana tanpa kesalahan dalam hukum positif kita ternomakan pada Pasal 6 ayat (2) Undang-undang Kekuasaan Kehakiman, yang berbunyi "tidak seorang pun dapat dijatuhi pidana, kecuali apabila pengadilan karena alat pembuktian yang sah menurut undang-undang, mendapat keyakinan bahwa seseorang yang dianggap dapat bertanggung jawab, telah bersalah atas perbuatan yang didakwakan atas dirinya".

Sehingga seseorang dapat dipidana dengan memperhatikan perbuatan tindak pidananya sebagai bentuk dari pertanggungjawaban pidana apakah memang terbukti perbuatan yang telah dilakukan tersebut memang suatu kesalahan yang diperbuat baik dengan kesengajaan ataupun dengan kelalaiannya dengan suatu bentuk kejahatan ataukah hanya suatu bentuk dari pelanggaran . Dengan memperhatikan unsur dari kejahatan dan batin pelaku kejahatan. "Bahwa suatu perbuatan dianggap telah melanggar hukum dan dapat dikenakan sanksi pidana, harus dipenuhi dua unsur, yaitu adanya unsur actus reus (physical element) dan unsur mens rea (mental element). Unsur actus reus adalah esensi dari kejahatan itu sendiri atau perbuatan yang dilakukan, sedangkan unsur mens rea adalah sikap batin pelaku pada saat melakukan perbuatan". ${ }^{12}$

c. Tidak adanya alasan pemaaf terhadap perbuatan pidana yang telah terjadi.

Didalam hukum pidana kita mengenal teori alasan pembenar, alasan pemaaf dan alasan penghapus tuntutan. Menurut Memorie van Toelichting (M.v.T): ${ }^{13}$

1. Alasan-alasan penghapus pidana.

a. Alasan yang terdapat dalam batin terdakwa, misal sebagaimana diatur dalam Pasal 44 KUHP.

b. Alasan di luar batin terdakwa, misal sebagaimana diatur dalam Pasal 48-51 KUHP.

2. Alasan pembenar.

Alasan yang menghapus sifat melawan hukumnya tindak pidana, sehingga perbuatan terdakwa menjadi patut dan benar.

1) Pasal 49 ayat (1) KUHP, pembelaan terpaksa.

2) Pasal 50 KUHP, melaksanakan ketentuan Undang-undang.

3) Pasal 51 ayat (1) KUHP, melaksanakan perintah atasan.

3. Alasan pemaaf.

\footnotetext{
${ }^{12}$ Zainal Abidin Farid, 1995, h. 35

${ }^{13}$ Didik Endro Purwoleksono, op.cit, 2014, h. 76
} 
Alasan yang menghapus kesalahan terdakwa, jadi di sini perbuatan terdakwa tetap merupakan tindak pidana, tetapi tidak dapat dipidana karena tidak adanya kesalahan.

1) Pasal 49 ayat (2) KUHP, pembelaan melampui batas.

2) Pasal 51 ayat (2) KUHP, perintah atasan yang tidak berhak dijalankan dengan itikad baik.

4. Alasan penghapus penuntutan.

Dalam hukum acara pidana dikenal dengan asas oportunitas, hal ini diatur di dalam Pasal 35 Undang-undang Kejaksaan.

Berdasarkan dari pemahaman singkat terkait pertanggungjawaban pidana maka kita juga harus mengetahui sifat dari hukum pidana itu sendiri. Menurut Van Hattum, ${ }^{14}$ memandang hukum pidana dewasa ini sebagai hukum publik, yang mana ini merupakan perkembangan baru, karena dahulu bersifat hukum privat.

Roeslan Saleh" ${ }^{15}$ menyatakan bahwa "Dalam pengertian perbuatan pidana tidak termasuk hal pertanggungjawaban. Perbuatan pidana hanya menunjuk kepada dilarangnya perbuatan. Apakah orang yang telah melakukan perbuatan itu kemudian juga dipidana, tergantung pada soal apakah dia dalam melakukan perbuatan itu memang mempunyai kesalahan atau tidak. Apabila orang yang melakukan perbuatan pidana itu emang mempunyai kesalahan, maka tentu dia akan dipidana". Sehingga seseorang secara garis besar dapat dipidana berdasarkan ada unsur melawan hukum, unsur obyektif, dan ada unsur kesalahan dalam bentuk kesengajaan dan atau kealpaan, unsur subjektif. Maka terjadinya pertanggungjawaban pidana secara umum adalah dengan terpenuhinya unsur pertanggungjawaban pidana terhadap tindak pidana atau perbuatan yang telah dilakukan oleh seseorang yang menghasilkan sebuah kejahatan. Sehingga pelaku yang telah melakukan tindak pidana tersebut sudah sepatutnya menerima sanksi yang telah ditetapkan oleh Undang-undang yang berlaku.

Pelaku tindak pidana Narkotika harus mempertanggungjawabkan perbuatannya apabila perbuatannya bertentangan dengan UU No. 35 Tahun 2009. Pertanggungjawaban pelaku tindak pidana Narkotika berbeda-beda sesuai dengan perbuatan yang telah dilakukannya maupun jenis Narkotika yang disalahgunakan sesuai dengan ketentuan pidana yang telah tercantum dalam UU No. 35 Tahun 2009.

\footnotetext{
${ }^{14}$ Andi Hamzah, Asas-asas hukum pidana,edisi revisi, tahun 2008, h. 7

${ }^{15}$ Roeslan Saleh, Op.cit, 1982, h. 75
} 
Ketentuan pidana terhadap pertanggungjawaban pidana Narkotika terkait Narkotika Golongan I dirumuskan dalam Pasal 111 sampai dengan Pasal 116 UU No. 35 Tahun 2009, antara lain:

a. Pasal 111 ayat (1) menentukan bahwa: Setiap orang yang tanpa hak atau melawan hukum menanam, memelihara, memiliki, menyimpan, menguasai, atau menyediakan Narkotika Golongan I dalam bentuk tanaman, dipidana dengan pidana penjara paling singkat 4 (empat) tahun dan paling lama 12 (dua belas) tahun dan pidana denda paling sedikit Rp 800.000.000,00 (delapan ratus juta rupiah) dan paling banyak Rp 8.000.000.000,00 (delapan miliar rupiah).

b. Pasal 112 ayat (1) menentukan bahwa: Setiap orang yang tanpa hak atau melawan hukum memiliki, menyimpan, menguasai, atau menyediakan Narkotika Golongan I bukan tanaman, dipidana dengan pidana penjara paling singkat 4 (empat) tahun dan paling lama 12 (dua belas) tahun dan pidana denda paling sedikit $\mathrm{Rp} 800.000 .000,00$ (delapan ratus juta rupiah) dan paling banyak Rp 8.000.000.000,00 (delapan miliar rupiah).

c. Pasal 113 ayat (1) menentukan bahwa: Setiap orang yang tanpa hak atau melawan hukum memproduksi, mengimpor, mengekspor, atau menyalurkan Narkotika Golongan I, dipidana dengan pidana penjara paling singkat 5 (lima) tahun dan paling lama 15 (lima belas) tahun dan pidana denda paling sedikit Rp 1.000.000.000,00 (satu miliar rupiah) dan paling banyak Rp 10.000.000.000,00 (sepuluh miliar rupiah).

d. Pasal 114 ayat (1) menentukan bahwa: Setiap orang yang tanpa hak atau melawan hukum menawarkan untuk dijual, menjual, membeli, menerima, menjadi perantara dalam jual beli, menukar, atau menyerahkan Narkotika Golongan I, dipidana dengan pidana penjara seumur hidup atau pidana penjara paling singkat 5 (lima) tahun dan paling lama 20 (dua puluh) tahun dan pidana denda paling sedikit Rp 1.000.000.000,00 (satu miliar rupiah) dan paling banyak Rp 10.000.000.000,00 (sepuluh miliar rupiah).

e. Pasal 115 ayat (1) menentukan bahwa: Setiap orang yang tanpa hak atau melawan hukum membawa, mengirim, mengangkut, atau mentransito Narkotika Golongan I, dipidana dengan pidana penjara paling singkat 4 (empat) tahun dan paling lama 12 (dua belas) tahun dan pidana denda paling sedikit Rp 800.000.000,00 (delapan ratus juta rupiah) dan paling banyak Rp 8.000.000.000,00 (delapan miliar rupiah).

f. Pasal 116 ayat (1) menentukan bahwa: Setiap orang yang tanpa hak atau melawan hukum menggunakan Narkotika Golongan I terhadap orang lain atau memberikan Narkotika Golongan I untuk digunakan orang lain, dipidana dengan pidana penjara paling singkat 5 (lima) tahun dan paling lama 15 (lima belas) tahun dan pidana denda paling sedikit Rp 1.000.000.000,00 (satu miliar rupiah) dan paling banyak $\mathrm{Rp}$ 10.000.000.000,00 (sepuluh miliar rupiah).

Berdasarkan pasal-pasal tersebut di atas menunjukkan bahwa sanksi yang diatur dalam UU No. 35 Tahun 2009 memuat ketentuan minimum dan maksimum.

Tindak pidana Narkotika merupakan salah satu kejahatan luar biasa 
(extraordinary crime) sehingga perlu dilakukan pemberantasan secara luar biasa seperti pemberatan ancaman sanksi pidana.

Pengaturan pidana minimal khusus dalam UU No. 35 Tahun 2009 menimbulkan asumsi bahwa undang-undang itu bertujuan untuk memberikan hukuman yang berat terhadap pelaku tindak pidana dalam memberantas tindak pidana Narkotika. Sedangkan pengaturan pidana maksimum khusus bertujuan untuk mencegah tindakan hakim yang sewenang-wenang dalam menjatuhkan putusan pemidanaan agar tidak melebihi batas yang telah ditentukan dalam undang-undang. Hal itu berarti hakim tidak dapat menjatuhkan pidana melebihi ketentuan pidana maksimum khusus yang telah diatur dalam undang-undang karena terdakwa juga harus mendapat perlindungan hukum. Peraturan perundangundangan yang berlaku di Indonesia sedikit banyak dipengaruhi oleh kecenderungan internasional.

Menurut Muladi, dikembangkannya sanksi minimum khusus untuk tindak pidana tertentu merupakan salah satu dari 7 (tujuh) kecenderungan internasional. Kecenderungan internasional tersebut yaitu sebagai berikut:

1. Kecenderungan untuk mencari sanksi alternatif dari pidana kemerdekaan (alternative sanction);

2. Dikembangkannya sanksi minimum khusus untuk tindak pidana tertentu;

3. Diaturnya sistem pidana kumulatif untuk tindak pidana tertentu;

4. Polarisasi pidana mati;

5. Dikembangkannya pidana terhadap korporasi;

6. Penggunaan sistem dua jalur (double track system);

7. Pengaturan secara khusus sistem pidana anak. ${ }^{16}$

Lebih lanjut Muladi menjelaskan bahwa dikembangkannya sanksi minimum khusus untuk pidana tertentu ditujukan dalam rangka mengurangi disparitas pidana (disparity of sentencing) dan menunjukkan beratnya tindak pidana yang bersangkutan. ${ }^{17}$ Pendapat Muladi ini sama halnya dengan yang disampaikan oleh Barda Nawawi Arief yang menyatakan bahwa "Perlunya minimal khusus ini dapat dirasakan dari keresahan masyarakat atau kekurang puasan warga masyarakat terhadap pidana penjara yang selama ini dijatuhkan dalam praktek, terutama

\footnotetext{
${ }^{16}$ Muladi, Hak Asasi Manusia, Politik, dan Sistem Peradilan Pidana, Badan Penerbit Universitas Diponegoro, Semarang, 2002, h. 15

${ }^{17}$ Ibid, h. 155
} 
pidana yang tidak jauh berbeda antara pelaku tindak pidana kelas kakap dengan pelaku tindak pidana kelas teri.",18

Berdasarkan pendapat ahli di atas menunjukkan bahwa tindak pidana narkotika merupakan salah satu tindak pidana yang berat dan serius karena UU No. 35 Tahun 2009 mengatur tentang ketentuan pidana minimum khusus. Selain itu, pidana minimum khusus secara umum bertujuan untuk mengurangi disparitas pidana dalam menjamin kepastian hukum dan secara khusus untuk memberikan efek jera bagi pelaku tindak pidana. Hal itu diperkuat berdasarkan penjelasan atas UU No. 35 Tahun 2009 yang menyebutkan bahwa: Dalam kenyataannya tindak pidana Narkotika di dalam masyarakat menunjukkan kecenderungan yang semakin meningkat baik secara kuantitatif maupun kualitatif dengan korban yang meluas, terutama di kalangan anak-anak, remaja, dan generasi muda pada umumnya. Tindak pidana Narkotika tidak lagi dilakukan secara perseorangan, melainkan melibatkan banyak orang yang secara bersama-sama, bahkan merupakan satu sindikat yang terorganisasi dengan jaringan yang luas yang bekerja secara rapi dan sangat rahasia baik di tingkat nasional maupun internasional. Karena itu untuk menimbulkan efek jera terhadap pelaku penyalahgunaan dan peredaran gelap Narkotika dan Prekursor Narkotika, diatur mengenai pemberatan sanksi pidana, baik dalam bentuk pidana minimum khusus, pidana penjara 20 (dua puluh) tahun, pidana penjara seumur hidup, maupun pidana mati. Selain pidana minimum khusus, pemberatan hukuman dalam UU No. 35 Tahun 2009 juga dapat dilihat dari sifatnya yaitu bersifat kumulatif artinya bahwa apabila seseorang terbukti melakukan tindak pidana narkotika maka akan dikenakan hukuman pidana penjara dan pidana denda.

\section{KESIMPULAN}

Berdasarkan pemahaman yang sudah dibahas di atas, maka bagi pelaku tindak pidana sudah selayaknya agar dapat dikenai sanksi pidana terhadap perbuatan pidana yang telah dilakukan khususnya kejahatan Narkotika yang menggunakan sarana teknologi, dan sudah menjadi kewajiban dan keharusan bahwa unsur-unsur pertanggungjawaban pidana yang berkaitan dengan kejahatan Narkotika yang menggunakan teknologi berbasis internet dan aplikasi VPN di

\footnotetext{
${ }^{18}$ Barda Nawawi Arief, Masalah Pidana Perampasan Kemerdekaan dalam KUHP Baru, Masalah-Masalah Hukum No. Edisi Khusus, Universitas Diponegoro, Semarang, 1987, h. 84
} 
Indonesia dari sisi Undang-undang Narkotik harus sudah terpenuhi secara mutlak sebelum pelaku dapat dihukum pidana. Dengan kata lain hukum pidana dengan keunikannya tetap menerapkan prinsip kehati-hati di dalam memberikan sanksi pidananya terhadap pelaku perbuatan pidana dengan memperhatikan unsur pertanggungjawaban pidananya apakah sudah terpenuhi. Mengingat menurut pendapat ahli bahwa tindak pidana Narkotika merupakan salah satu tindak pidana yang berat dan serius karena UU No. 35 Tahun 2009 mengatur tentang ketentuan pidana minimum khusus. Hal ini dimaksudkan agar dapat memberikan efek jera terhadap para pengedar dan pembelajaran kepada para pengguna Narkotika.

\section{SARAN}

Pemerintah perlu mengeluarkan regulasi khusus yang mengatur akan pemberian sanksi pidana terhadap pengedar Narkotika yang menggunakan teknologi berbasis internet dan aplikasi VPN di Indonesia dari sisi Undangundang Narkotika dan Undang-undang ITE, hal ini dikarenakan sampai dengan saat ini setiap pengedar Narkotika yang menggunakan teknologi berbasis internet dan aplikasi VPN di Indonesia untuk mengedarkan Narkotika hanya dipidana dengan menggunakan sisi Undang-undang Narkotika bukan Undang-undang ITE. Hal ini dimaksudkan agar terciptanya kepastian hukum didalam negara tercinta Indonesia.

\section{DAFTAR BANCAAN}

\section{Buku}

Arief, Barda Nawawi, Masalah Pidana Perampasan Kemerdekaan dalam KUHP Baru, Masalah-Masalah Hukum No. Edisi Khusus, Universitas Diponegoro, Semarang, 1987.

Hamzah, Andi, Asas-asas hukum pidana,edisi revisi, tahun 2008.

Muladi, Hak Asasi Manusia, Politik, dan Sistem Peradilan Pidana, Badan Penerbit Universitas Diponegoro, Semarang, 2002.

Purwoleksono, Didik Endro, Hukum Pidana, Airlangga University Press, 2014.

Saleh, Roeslan, Pikiran-pikiran Tentang Pertanggungjawaban Pidana, Ghalia Indonesia, Jakarta, 1982.

Sianturi, S.R., Asas-Asas Hukum Pidana Indonesia dan Penerapannya, Cet. IV, Alumni Ahaem-Pateheam, Jakarta, 1996. 


\section{Peraturan per-Undang-undangan}

Undang-undang Dasar 1945 NRI

Undang-undang No. 1 Tahun 1946 tentang KUHP

Undang-undang No. 8 Tahun 1981 tentang KUHAP

Undang-undang No. 22 tahun 1997 tentang Narkotika

Undang-undang No. 39 Tahun 1999 tentang Hak Asasi Manusia

Undang-undang No. 8 Tahun 2008 tentang Informasi dan Transaksi Elektronik.

Undang-undang No. 35 tahun 2009 tentang Narkotika

Undang-undang No. 19 Tahun 2016 tentang Perubahan Atas Undang-undang No.

8 Tahun 2008 tentang Informasi dan Transaksi Elektronik

\section{Website}

http://repository.uksw.edu/bitstream/123456789/9106/2/T0_562011007_BAB\%20 II.pdf.

http://technopark.surakarta.go.id/id/media-publik/komputer-teknologiinformasi/191-ip-address-fungsi-dan-kelas-ip

https://www.it-jurnal.com/pengertian-vpn-virtual-private-network/

http://guntur.staff.gunadarma.ac.id/Downloads/files/40272/Pertemuan+8++ Kasus+\%26+UU+ITE.ppt

Aris Irawan, Undang-undang No. 35 Tahun 2009 tentang Narkotika bila dikaji dari Politik Hukum Penerapannya, http://ilmuhukum.umsb.ac.id/?id=177. 